\title{
РОЛЬ МІЖНАРОДНОї ТОРГІВЛІ В ДІЯЛЬНОСТІ ПІДПРИЄМСТВ ЄВРОПЕЙСЬКОГО СОЮЗУ
}

\section{ROLE OF INTERNATIONAL TRADE IN THE ACTIVITIES OF EUROPEAN UNION COMPANIES}

\author{
Насипайко Дар'я Сергіївна \\ кандидат економічних наук, доцент, \\ Центральноукраїнський національний технічний університет \\ ORCID: https://orcid.org/0000-0001-5736-2406 \\ Подплєтній Валерій Володимирович \\ кандидат економічних наук, доцент, \\ Центральноукраїнський національний технічний університет \\ ORCID: https://orcid.org/0000-0001-5746-3370 \\ Nasypaiko Daria, Podpletniy Valerii \\ Central Ukrainian National Technical University
}

Проведено дослідження ролі міжнародної торгівлі в діяльності підприємств Європейського Союзу. Основною метою проведеного дослідження $€$ характеристика ролі міжнародної торгівлі у діяльності підприємств. Визначено, що в умовах глобалізації та застосування знань в економіці Європейського Союзу, відкриваються нові можливості для компаній і розвитку міжнародної торгівлі. Доведено, що незалежно від застосовуваних методів розвитку міжнародної торгівлі, найбільш активними з торгових компаній є міжнародні торгові компанії. Встановлено, що по всьому Європейському Союзу сформовано єдиний простір, який працює за загальними стандартами. Технології електронної комерції неактивно використовуються у розвитку міжнародної торгівлі у згаданому просторі. Сфрормовано, що міжнародна торгівля являє собою складне явище соціальноекономічного розвитку, що характеризується динамізмом, що виявляється в численних змінах.

Ключові слова: торгівля, міжнародна торгівля, підприємства, Європейський Союз, діяльність підприємств.

Проведено исследование роли международной торговли в деятельности предприятий Европейского Союза. Основной целью проведенного исследования является характеристика роли международной торговли в деятельности предприятий. Определено, что в условиях глобализации и применения знаний в экономике Европейского Союза открываются новые возможности для компаний и развития международной торговли. Доказано, что независимо от применяемых методов развития международной торговли, наиболее активными из торговых компаний являются международные торговые компании. Установлено, что по всему Европейскому Союзу ссормировано единое пространство, работающий по общим стандартам. Технологии электронной коммерции неактивно используются в развитии международной торговли в упомянутом пространстве. Сорормировано, что международная торговля представляет собой сложное явление социальноэкономического развития, характеризующийся динамизмом, что проявляется в многочисленных изменениях.

Ключевые слова: торговля, международная торговля, предприятия, Европейский Союз, деятельность предприятий.

Development and enlargement of the European Union Processes help establish the principles of free movement of goods, services, capital and labor and increase the global competitiveness of European Union enterprises. Analysis of the literature suggests that business practices should be understood and analyzed when studying international trade. However, such studies do not pay much attention to research. Therefore, the article aims to reveal the ability of companies to develop international trade in modern challenges, to compare economic operators operating in different countries, to assess whether companies are able to respond and adequately adapt to new circumstances. The study of the role of international trade in the activities of enterprises of the European Union has been carried out. The main purpose of the study is to characterize the role of international trade in the activities of enterprises. It is determined that in the context of globalization and the application of knowledge in the economy of the European Union, new opportunities open up for companies and the development of international trade. It has been proven that regardless of the methods used for the development of international trade, the most active trading companies are inter- 
national trading companies. It has been established that a single space has been formed throughout the European Union, working according to common standards. E-commerce technologies are inactively used in the development of international trade in this space. Formed that international trade is a complex phenomenon of socio-economic development, characterized by dynamism, which is manifested in numerous changes. The survey results show that international trade companies face not only difficulties in transporting goods, but also customs duties, linguistic and cultural differences, and currency conversion risks. Therefore, in general, business entities engaged in international trade should be more prepared than entities that sell goods only on national markets. The volume of international trade of European Union companies accounts for the largest share in the structure of world trade.

Keywords: trade, international trade, enterprises, European Union, activities of enterprises.

Постановка проблеми. Міжнародна торгівля - це складне явище соціально-економічного розвитку, що характеризується динамізмом, що виявляється в численних змінах. На це явище впливають такі процеси, як глобалізація, застосування знань в економіці, розвиток та розширення Європейського Союзу: наростаюча глобалізація веде до появи глобальних ринків, розповсюдження технологій, збільшення застосування знань. Розвиток та розширення Європейського Союзу Процеси допомагає встановити принципи вільного руху товарів, послуг, капіталу та робочої сили, а також підвищити глобальну конкурентоспроможність підприємств Європейського Союзу. Аналіз літератури свідчить про те, що під час вивчення міжнародної торгівлі слід розуміти та аналізувати ділові практики. Однак такі дослідження не приділяють великої уваги дослідженням. Тому стаття має на меті розкрити здатність компаній розвивати міжнародну торгівлю в сучасних викликах, порівнювати економічних операторів, що діють у різних країнах, оцінювати, чи здатні компанії реагувати та адекватно адаптуватися до нових обставин.

Аналіз основних досліджень і публікацій. В умовах сьогодення міжнародна торгівля відіграє ключову роль при прийнятті тих чи інших управлінських рішень та діяльності підприємств. Дослідженням даної проблематики займалися наступні вчені: І. В. Бурковський, Ю. В. Цьомик, П. М. Леоненко, П. І. Юхименко, С. М. Кваша, В. В. Клімчик, В. Г. Андрійчук та інші.

Віддаючи належне науковому здобутку провідних вчених, ми зазначимо, що сьогодні досі залишається не повністю розкритим питання визначення роль міжнародної торгівлі у діяльності підприємств.

Постановка завдання. Мета дослідження - охарактеризувати роль міжнародної торгівлі у діяльності підприємств.

Виклад основного матеріалу дослідження. Міжнародна торгівля, пов'язуючи всі країни світу в єдину міжнародну економічну систему - світову економіку, - займає в ній особливе місце, так як і історично, і логічно інтернаціоналізація всіх аспектів світової економіки починалася і починається саме зі сорери товарного обігу. Хоча в сучасних умовах обсяги прямого іноземного інвестування і перевищують обсяги міжнародної торгівлі, вона продовжує зберігати в системі міжнародних економічних відносин центральне місце, так як опосередковує практично всі види міжнародного поділу праці: спільну виробничу діяльність, міжнародний трансорерт технологій, ліцензування, фрранчайзинг і т. д.

В умовах глобалізації та застосування знань, в економіці Європейського Союзу відкриваються нові можливості для компаній і розвитку міжнародної торгівлі: вони сприяють більш активному використанню традиційних методів розвитку міжнародної торгівлі; для придбання фрабрик; для розвитку транснаціональних компаній; для розвитку торгівлі між підрозділами різних країн тощо [1-2].

Можна говорити про переваги від розвитку міжнародної торгівлі, а саме: продукція змінює свою матеріальну форму на нематеріальну, нові технології, що застосовуються в різних ссрерах, швидко поширюються між компаніями та населенням; їх застосування дозволяє зменшити витрати на торгівлю, збільшити обсяг продажів. 3 новими шляхами розвитку міжнародної торгівлі як матеріальні, так і нематеріальні товари зазвичай продаються через Інтернет за допомогою технологій електронної комерції. Застосовуючи технології електронної комерції, покупці та продавці стають менш залежними від часу та місця: покупці можуть купувати товари в будь-який час доби, в будьякій точці світу, не виходячи з дому.

Продавці можуть конкурувати за покупців не тільки на національному, а й на міжнародних ринках. Наприклад, у країні з великим внутрішнім ринком економічні оператори, як правило, купують більше. Оператори в країнах, які добре підходять для природних ресурсів, таких як насрта, як правило, продають більше. I так звані країни, оточені землею, які не мають прямого доступу до морських портів, стикаються 3 труднощами при перевезенні 
вантажів у процесі розвитку зовнішньої торгівлі через значно вищі ціни на транспорт.

Результати дослідження свідчать, що компанії, що займаються міжнародною торгівлею, стикаються не тільки з труднощами при перевезенні товарів, але й з митними зборами, мовними та культурними відмінностями та ризиками конвертації валют. Тому загалом суб'єкти господарювання, що займаються міжнародною торгівлею, повинні бути більш підготовленими, ніж суб'єкти, які продають товари лише на національних ринках. На обсяги міжнародної торгівлі компаній Європейського Союзу припадає найбільша частка в структурі світової торгівлі [3-5].

Вивчаючи обсяги міжнародної торгівлі компаній Європейського Союзу, помічається, що найбільш активно міжнародна торгівля здійснюється виробничими та торговими компаніями. У структурі обсягу міжнародної торгівлі Європейського Союзу обсяг міжнародної торгівлі виробництвом і торговими підприємствами $€$ найбільшим і становить 82,4\% від загального обсягу міжнародної торгівлі в Європейському Союзі. Зрозуміло, що компанії Європейського Союзу (особливо виробничі та торгові) повинні активно прагнути застосовувати традиційні та нові шляхи розвитку міжнародної торгівлі у відповідь на зміни, спричинені глобалізацією, застосуванням знань в економіці, розвитком та розширенням Європейський Союз.

За даними Євростату, 23\% виробничих та 9,4\% торгових компаній торгують на міжнародному рівні: 13,5\% виробничих та 5,8\% торгових компаній продають в інших країнах Європейського Союзу, 9,4\% виробничих та 3,7\% торгових компаній за межами Європейського Союзу. Зазначається, що 23,7\% загального доходу виробничих компаній та 6\% загального доходу торгових компаній становлять доходи від продажу товарів на міжнародних ринках. Також виявляється, що кількість як виробничих, так і торгових компаній, що займаються міжнародною торгівлею, щороку збільшується. Незалежно від методів розвитку міжнародної торгівлі, що використовуються торговими компаніями Європейського Союзу, найбільш активно міжнародна торгівля здійснюється оптовими компаніями (вони становлять чверть усіх торгових компаній). 11,9\% оптових компаній продають товари в інших країнах Європейського Союзу, 9,8\% - за межами територій Європейського Союзу. Із загального доходу оптових підприємств, 10,7\% становлять доходи, отримані від продажу товарів на міжнародних ринках (приблизно три чверті-доходи від продажу товарів в інших країнах Європейського Союзу). Міжнародна торгівля особливо активна в оптових компаніях, що мають понад 10 працівників: 44\% з них продають товари в інших країнах Європейського Союзу, 33,6\% - поза межами Європейського Союзу. Однак слід зазначити, що серед усіх торгових компаній (включаючи оптову торгівлю) є небагато (менше 10\%) компаній, що мають понад 10 працівників [1].

Слід зазначити, що торгові компанії здебільшого використовують традиційні методи розвитку міжнародної торгівлі, а отже, більша частина доходу від торгівлі через Інтернет збирається на національних ринках. Наприклад, іспанські та німецькі купці збирають лише $10 \%$, Великобританія - 11\%, а Литва 14\% доходу від продажів в Інтернеті при продажу товарів в інших країнах.

В цілому, торгові компанії ЄС збирають 13\% своїх доходів від торгівлі в Інтернеті у міжнародній торгівлі. Більшість компаній ЄС продають товари через Інтернет у кількох країнах ЄС і лише $4 \%$ у десяти або більше країнах-членів. Також помітно, що компанії Європейського Союзу застосовують територіальні обмеження у своїй торгівлі, включаючи міжнародну торгівлю. Наприклад, 59\% інтернет-магазинів працюють лише однією мовою, часто продавці товарів переривають процес онлайн-покупок, коли особа, яка купує товар, вводить дані кредитної картки, і виявляється, що адреса знаходиться поза цільовим ринком продавця або продавці забороняють переглядати пропозиції, призначені для відвідувачів електронних магазинів, що проживають в інших країнах Європейського Союзу, або ж відмовляються продавати та доставляти товари покупцям, які проживають у країнах, де продавці не мають власного відділення.

Одними 3 найбільших експортерів серед країн Європейського Союзу за 2019 рік є: Німеччина, Франція та Нідерланди (рис. 1).

Споживачів в інших країнах можна вважати найважливішим фрактором, що перешкоджає розвитку міжнародної торгівлі. Також помітно, що по всьому Європейському Союзу сформовано єдиний простір, який працює за загальними стандартами. Технології електронної комерції не активно використовуються у розвитку міжнародної торгівлі у згаданому просторі.

Висновки 3 проведеного дослідження. Помітно, що по всій території Європейського Союзу сорормовано єдиний простір, який працює за загальними стандартами. Вищезгаданий простір не активно використовує технології електронної комерції у розвитку міжнародної торгівлі. шляхи розвитку міжнародної торгівлі. Встановлено, що незалежно від застосовуваних методів розвитку міжнародної торгівлі, най- 


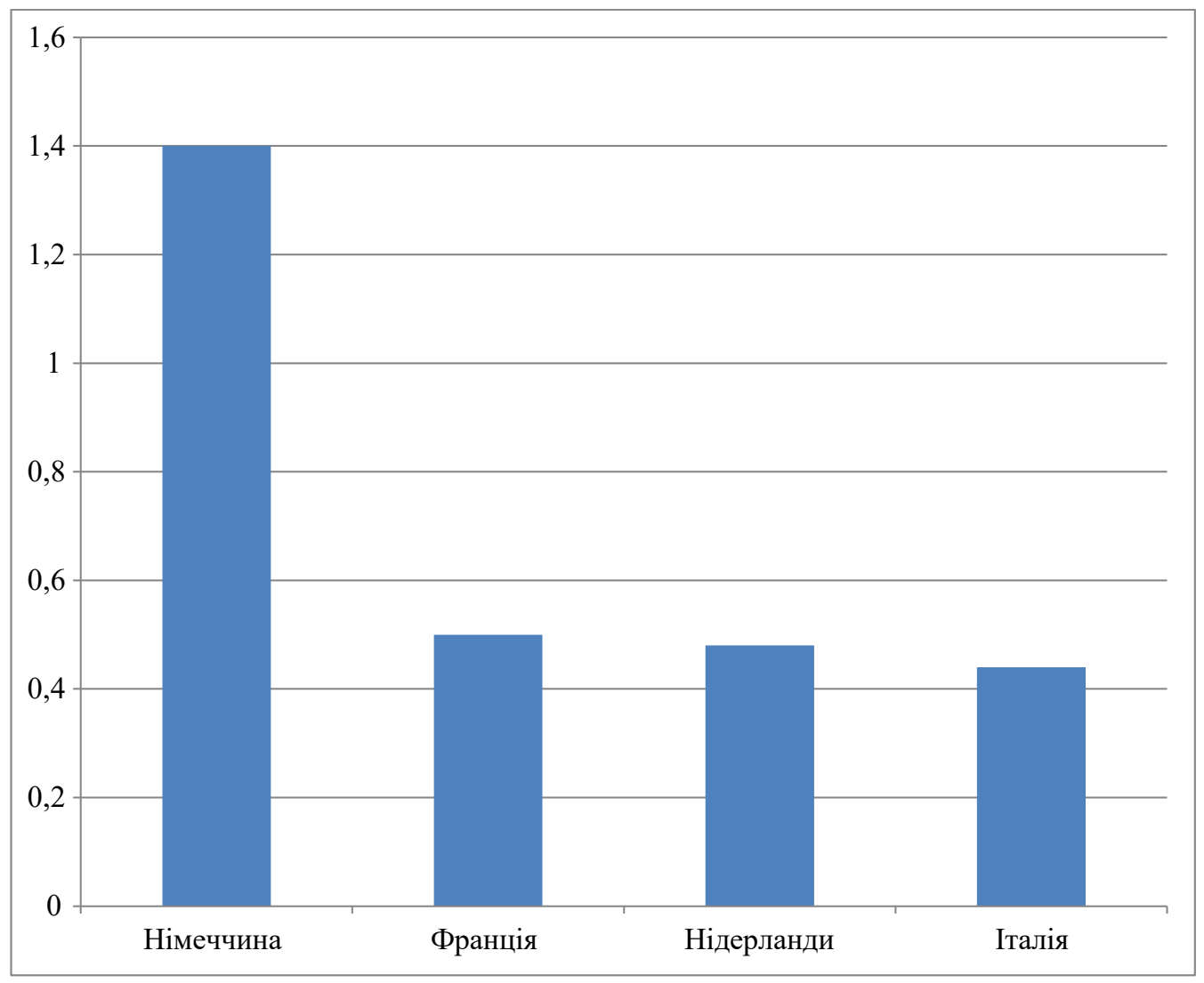

Рис. 1. Найбільші країни-експортери Європейського Союзу, трлн. грн. [1]

більш активними з торгових компаній є міжнародні торгові компанії. Також було зазначено, що недостатня увага приділяється міжнародній торгівлі в торгових компаніях, що мають до 10 працівників, та в неоптових компаніях, оскільки ці компанії найактивніше розвивають міжнародну торгівлю і найкраще поєднують різні шляхи розвитку міжнародної торгівлі.

\section{СПИСОК ВИКОРИСТАНИХ ДЖЕРЕЛ:}

1. Eurostat. Database catalogue [online]. 2019 [cited 10 January 2019]. Available from Internet: http://ec.europa.eu/eurostat/

2. Ulaşan, B. (2015).Trade openness and economic growth: panel evidence. Appl. Econ. Lett. 22(2), 163-167.

3. Zahonogo, P. (2016). Trade and economic growth in developing countries: Evidence from sub-Saharan Africa. Journal of African Trade, 3(1-2), 41-56.

4. Valles, G. (2014). Evolution of the International Trading System and Its Trends from a Development Perspective. Trade and Development Board, Sixty-First Session, 13.

5. R. Chang, L. Kaltani, N.V. Loayza (2019). Openness can be good for growth: the role of policy complementariness J. Dev. Econ., 90(1), pp. 33-49.

\section{REFERENCES:}

1. Eurostat. Database catalogue [online] (2019) [cited 10 January 2019]. Available from Internet: http://ec.europa.eu/eurostat/

2. Ulaşan, B. (2015).Trade openness and economic growth: panel evidence. Appl. Econ. Lett.

3. Zahonogo, P. (2016). Trade and economic growth in developing countries: Evidence from sub-Saharan Africa. Journal of African Trade.

4. Valles, G. (2014). Evolution of the International Trading System and Its Trends from a Development Perspective. Trade and Development Board, Sixty-First Session, 13.

5. R. Chang, L. Kaltani, N.V. Loayza (2019). Openness can be good for growth: the role of policy complementariness J. Dev. Econ. 